\title{
BIODEGRADASI ZAT WARNA REMAZOL YELLOW FG DALAM SISTEM SUSPENSI AKTIF
}

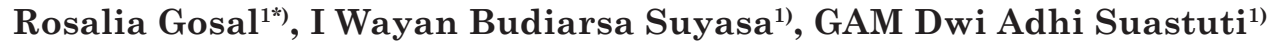 \\ 1)Jurusan Kimia FMIPA Universitas Udayana, Bukit Jimbaran, Bali \\ *Email : rosalia.gosal@yahoo.com
}

\begin{abstract}
BIODEGRADATION PIGMENT OF REMAZOL YELLOW FG COLOR IN ACTIVE SUSPENSION SYSTEM
\end{abstract}

\begin{abstract}
Remazol Yellow FG is used in the textile industry in the process of dyeing and chromatic system. The waste of Remazol Yellow FG is dangerous for ecosystem and human health if it is thrown into the environment. This research was conducted the application of waste execution that is biodegradation of Remazol Yellow FG dye in activated suspension. The aim of this research are : 1) to obtain the optimum time of microorganisms growth of sediment which taken from mangrove ecosystem of Serangan area, 2) to determine the optimum composition in declining the rate of Remazol Yellow FG waste, 3) to determine the rapid of Remazol Yellow $F G$ rate decline, 4) to know effectivity and microbial system that play role in biodegradation process. The textile waste used in this research was artificial waste from Remazol Yellow FG dye with concentration of $49,126 \mathrm{mg} / \mathrm{L}$. In the first phase, it observed the growth of microorganisms which is determined by determining the highest value of VSS (Volatile Suspended Solid) as the optimum time of bacteria capable of degrading Remazol Yellow FG. Furthermore, using the optimum time, the optimal composition is determined by observing the decrease levels of Remazol Yellow FG. The rate of decrease observed from the decreased levels of Remazol Yellow FG in biodegradation process for 7 days. The effectivity obtained from percentage of Remazol Yellow FG levels contained at the time of processing. Besides, there was an identification of microorganisms that take a role in biodegradation process of Remazol Yellow FG. The results showed that 12 hours is required to obtain the optimum time of microorganism growth with highest value $28000 \mathrm{mg} / \mathrm{L}$ of VSS after added into means containing the Remazol Yellow FG. The optimum composition in decreasing Remazol Yellow FG rate were composition I consisting of $900 \mathrm{~mL}$ glucose, $1950 \mathrm{~mL}$ Remazol Yellow FG waste, and $150 \mathrm{~mL}$ suspended grown that can reduce levels of waste from 49,126 mg/L to 34,573 mg/L. Decreased levels of Remazol Yellow FG with anaerobic-aerobic treatment for 7 days decreased from 49,126 $\mathrm{mg} / \mathrm{L}$ to 3,6039 $\mathrm{mg} / \mathrm{L}$ and has 92,66\% effectivity. The identified bacteria and take dominant role in the process of biodegradation are Bacillus sp, Coliform, Pseudomonas sp and Staphylococcus sp. Observation number of colonies in the early processing as amounted $2,84 \times 102 \mathrm{CFU} / \mathrm{mL}$, in the middle of processing time at $1,24 \mathrm{X} 102 \mathrm{CFU} / \mathrm{mL}$, and at the end of biodegradation processing of 2,08x102 CFU / $\mathrm{mL}$.
\end{abstract}

Keywords: biodegradation, remazol yellow fg, activated suspension.

\section{PENDAHULUAN}

Pada industri tekstil, zat warna banyak digunakan pada proses pencelupan dan sistem pewarnaan lain. Zat warna yang banyak digunakan dalam industri tekstil yaitu zat warna reaktif. Salah satu jenis zat warna reaktif yang banyak digunakan dalam industri tekstil adalah zat warna Remazol Yellow FG menjadi pilihan karena tergolong murah sementara gugus kromofornya mudah sekali dalam memberikan warna-warna yang cerah dan tahan uji (Rasjid dkk, 1976). Kehadiran zat warna jenis ini dilingkungan memiliki sifat non-biodegradable atau susah diuraikan. Sulitnya penguraian zat warna ini disebabkan oleh komponen zat warna Remazol Yellow $F G$ sebagian besar tersusun atas zat warna azo dan turunannya merupakan turunan dari benzena yang sulit terdegradasi. Senyawa azo yang terlalu lama berada di lingkungan akan menjadi sumber penyakit karena bersifat karsinogen dan mutagenik (Sugiharto, 1987).

Untuk menghilangkan dampak negatif dari limbah zat warna, diperlukan suatu perlakuan untuk mengurangi atau bahkan menghilangkan limbah pewarna dengan cara tertentu agar tidak membahayakan dan mencemari lingkungan sekitar. Salah satu cara yang dapat dilakukan adalah dengan pengolahan biologi untuk mengurangi konsentrasi limbah pewarna agar tidak membahayakan dan mencemari lingkungan saat dibuang di alam (Manurung dkk, 2004). Penambahan suspensi aktif dalam penelitian yang dilakukan oleh Suyasa dan Dwijani ( 2015) mampu menurunkan kadar COD sebesar $117,32 \mathrm{mg} / \mathrm{L}$ selama 8 jam pengolahan. Aktivitas mikroorganisme dimanfaatkan untuk mendegradasi senyawa organik yang terkandung dalam limbah tekstil menjadi senyawa yang lebih sederhana dan tidak membahayakan bagi perairan. 
Metode biodegradasi diterapkan untuk melenyapkan bahan pencemar yang terkontaminasi dalam perairan. Keunggulan dari proses pengolahan air limbah dengan biodegradasi ini adalah pengolahannya sangat mudah, biaya operasi yang rendah dibandingkan dengan proses lumpur aktif, dan lumpur yang dihasilkan relatif sedikit.

Sungai Serangan memberikan kontribusi besar dalam pertumbuhan mikroorganisme zat warna tekstil yang mengandung zat warna sintetik khususnya Remazol Yellow FG, dimana Sungai Serangan tersebut banyak mengandung sampah, baik sampah organik maupun anorganik yang berasal dari dapur, pencelupan, percetakan, kamar mandi, laundry, dan lainnya. Dengan demikian diduga bahwa sedimen sungai Serangan mengandung mikroorganisme yang dapat mendegradasi zat warna Remazol Yellow FG. Pengolahan biodegradasi ini diawali dengan cara pembibitan untuk mengetahui waktu optimum pertumbuhan biomassa yang terkandung di dalam suspensi aktif yang digunakan. Suspensi aktif yang digunakan dalam penelitian ini bersumber dari ekosistem mangrove yang ada di daerah Serangan. Dalam penelitian ini ditentukan pula komposisi optimum untuk menurunkan kadar Remazol Yellow $F G$ untuk mengetahui komposisi terbaik yang dapat digunakan dalam proses biodegradasi zat warna Remazol Yellow FG. Sistem pengolahan biodegradasi ini diharapkan dapat bekerja secara efektif dalam menurunkan kadar Remazol Yellow FG.

\section{METODOLOGI}

\subsection{Penentuan Waktu Optimum Pertumbuhan} Mikroorganisme dalam Membuat Suspensi Aktif yang Ditambahkan dalam Media yang Mengandung Remazol Yellow FG

Sampel sedimen/tanah diambil dari sungai yang berlokasi di Serangan. Sedimen Sungai Serangan diambil menggunakan sekop dengan kedalaman 5 -

$10 \mathrm{~cm}$ dari permukaan dasar sebanyak \pm 100 gram.

Kemudian media selektif yang mengandung Remazol Yellow FG atau penumbuh bakteri pendegradasi limbah disiapkan yaitu $1,0 \mathrm{~g}$ sampel tanah; 0,5 g KH $\mathrm{PO}_{4}$; 0,5 g K $\mathrm{HPO}_{4 ;} 0,5$ g NH $\mathrm{NO}_{3}$; $0,1 \mathrm{~g} \mathrm{MgSO}{ }_{4} \cdot 7 \mathrm{H}_{2} \mathrm{O} ; 1,0 \mathrm{~g}$ Sodium Benzoat dan $0,01 \mathrm{~g}$ Remazol Yellow FG kemudian semua bahan dimasukkan kedalam gelas beaker 2 L kemudian ditambahkan akuades sebanyak $1000 \mathrm{~mL}$. Media pada gelas beaker diaerasi dengan menggunakan aerator yang diberi selang yang diletakan didasar gelas beaker. Gelas beaker ditutup dengan kain kasa dan diikat dengan karet lalu didiamkan selama 48 jam. Pada jam ke 6, 12, 28 dan 48 aerator dimatikan dan didiamkan beberapa saat selama 10-15 menit untuk mengetahui perkembangan isolat bakteri dengan mengukur nilai VSS (Volatile Suspended Solid).
Kemudian ditentukan waktu optimum pertumbuhan biomassa.

\subsection{Penentuan Pengaruh Komposisi Bibit} Mikroorganisme, Larutan Gula dan Remazol Yellow FG 49,126 mg/L terhadap Penurunan Kadar Remazol Yellow FG

Tiga buah ember berukuran 5 Liter, disiapkan dalam kondisi bersih. Sebanyak $150 \mathrm{~mL}$ suspensi aktif dimasukkan ke dalam masing-masing ember yang dikomposisikan menjadi 3 yaitu:

Komposisi media I berisi $900 \mathrm{~mL}$ larutan gula dan 1950 mL larutan Remazol Yellow FG 49,126 $\mathrm{mg} / \mathrm{L}$.

- Komposisi media II berisi $600 \mathrm{~mL}$ larutan gula dan 2250 mL larutan Remazol Yellow FG 49,126 $\mathrm{mg} / \mathrm{L}$.

Komposisi media III berisi $300 \mathrm{~mL}$ larutan gula dan 2550 mL larutan Remazol Yellow FG 49,126 $\mathrm{mg} / \mathrm{L}$.

Media pada masing-masing ember ditumbuhkan dan diaerasi sampai waktu optimum tercapai. Konsentrasi dari larutan Remazol Yellow FG masingmasing ember diukur menggunakan spektrofotometer UV-Vis.

\subsection{Penentuan laju penurunan kadar Remazol} Yellow FG, dan sistem mikrobial yang berperan dalam proses biodegradasinya.

Pipa plastik disiapkan sebagai media pengolahan secara anaerob. Pada pipa plastik dimasukkan sebanyak 3,9 L air limbah yang mengandung Remazol Yellow FG dengan konsentrasi 49,126 mg/ L dan suspensi aktif sebanyak $1 \mathrm{~L}$. Pipa kemudian ditutup dan didiamkan selama 3 hari. Selanjutnya setelah didiamkan selama tiga hari, kadar air limbah Remazol Yellow FG diukur menggunakan spektrofotometer UV-Vis. Selanjutnya air limbah hasil pengolahan secara anaerobik dalam pipa paralon dipindahkan ke dalam wadah berukuran $10 \mathrm{~L}$ yang telah berisi larutan gula sebanyak $1,8 \mathrm{~L}$ serta media cair yang mengandung bibit mikroorganisme sebanyak $300 \mathrm{~mL}$. Selanjutnya mikroorganisme kembali ditumbuhkan dengan cara diberi suplai oksigen (aerasi). Proses pengolahan biodegradasi Remazol Yellow FG dalam sistem mikrobial secara aerob dilakukan selama 96 jam. Setiap selang waktu 12 jam pengolahan, dilakukan pengambilan sampel air sebanyak $100 \mathrm{~mL}$ untuk analisis penurunan konsentrasi Remazol Yellow FG. Sebanyak $100 \mathrm{~mL}$ sampel pada awal pengolahan, pertengahan dan diakhir pengolahan diambil untuk mengetahui jumlah serta jenis koloni mikroorganisme selama proses biodegradasi. Analisis jenis dan jumlah mikroorganisme yang berperan dilakukan di Laboratorium Biologi Universitas Udayana. Sampling kadar awal konsentrasi Remazol Yellow $F G$ ditentukan pada waktu 0 jam, kemudian dilakukan sampling pada hasil pengolahan anaerob 
pada waktu 72 jam. Selanjutnya dilakukan sampling pada pengolahan aerob dengan variasi waktu selang 12 jam sampai 168 jam. Penurunan konsentrasi Remazol Yellow FG ditentukan dengan memplot grafik antara waktu pengolahan dan penurunan konsentrasi. Kurva yang mengalami penurunan konstan dianggap sebagai kadar akhir Remazol Yellow FG berdasarkan baku mutu air limbah domestik.

Unit pengolahan biodegradasi dibuat menggunakan pipa berukuran panjang $90 \mathrm{~cm}$ dan diameter $12 \mathrm{~cm}$. Pipa ini diposisikan dalam keadaan vertikal dan pada bagian bawah pipa dibuat kran setinggi $15 \mathrm{~cm}$ dari dasar permukaan pipa untuk mengalirkan efluen air limbah yang sudah memasuki keadaan anaerobik ( $\mathrm{Q}_{1}$ ) kemudian pengolahan dilanjutkan dalam kondisi aerobik di dalam aerobik chamber dan mengalirkan efluen air limbah hasil pengolahan aerobik $\left(\mathrm{Q}_{2}\right)$. Berikut Sistem pengolahan biodegradasi

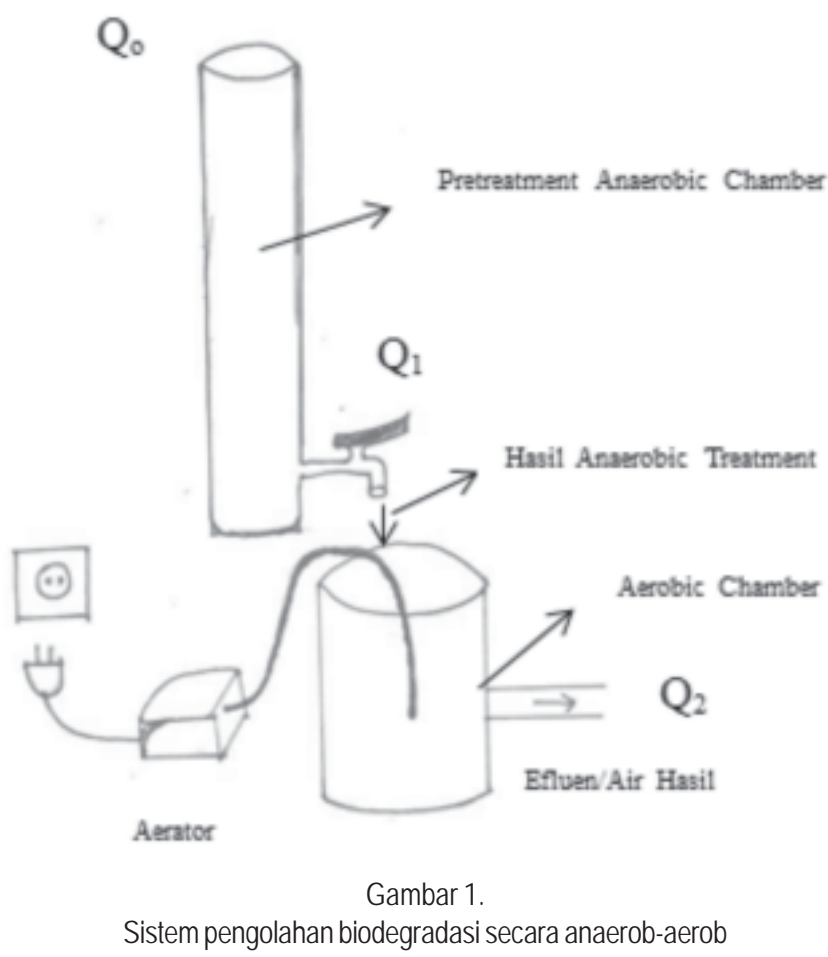

\subsection{Penentuan efektivitas biodegradasi zat warna Remazol Yellow FG}

Efektivitas pengolahan dari biodegradasi zat warna Remazol Yellow FG dalam sistem mikrobial dihitung berdasarkan efektivitas proses yang terjadi, yakni penurunan persentase kadar Remazol Yellow FG yang terkandung pada saat proses pengolahan. Hasil pengolahan kurang efektif apabila persentase efektivitas $<50 \%$, efektif 50\% - 80\%, dan sangat efektif apabila hasil $>80 \%$. Penurunkan kadar limbah zat warna azo ditentukan berdasarkan persamaan berikut (Metcalf dan Eddy, 2003).:

$\%$ Efektivitas $=\frac{(A-B)}{A} \times 100 \%$
Dimana, A = kadar Remazol Yellow FG awal (mg/L) dan B = kadar Remazol Yellow FG akhir.

\section{HASIL DAN PEMBAHASAN}

3.1. Waktu optimum Pertumbuhan Mikroorganisme dalam Suspensi Aktif yang Ditambahkan dalam Media yang Mengandung Remazol Yellow FG.

Penentuan waktu optimum pertumbuhan mikroorganisme dalam suspensi aktif diperoleh dari sampel sedimen sungai yang diawali dengan proses pembibitan. Pembibitan dilakukan dalam larutan media selama 48 jam. Berdasarkan hasil analisis nilai VSS ( Volatile Suspended Solid ) yang diamati selama 48 jam menunjukkan nilai VSS tertinggi yaitu pada jam ke 12 dan 28 yaitu sebesar 28000 mg/L. VSS ( Volatile Suspended Solid) yang merupakan nilai dari konsentrasi padatan tersuspensi yang menguap dan umum digunakan sebagai perkiraan konsentrasi mikroorganisme dalam unit penanganan biologi (Suyasa, 2015).

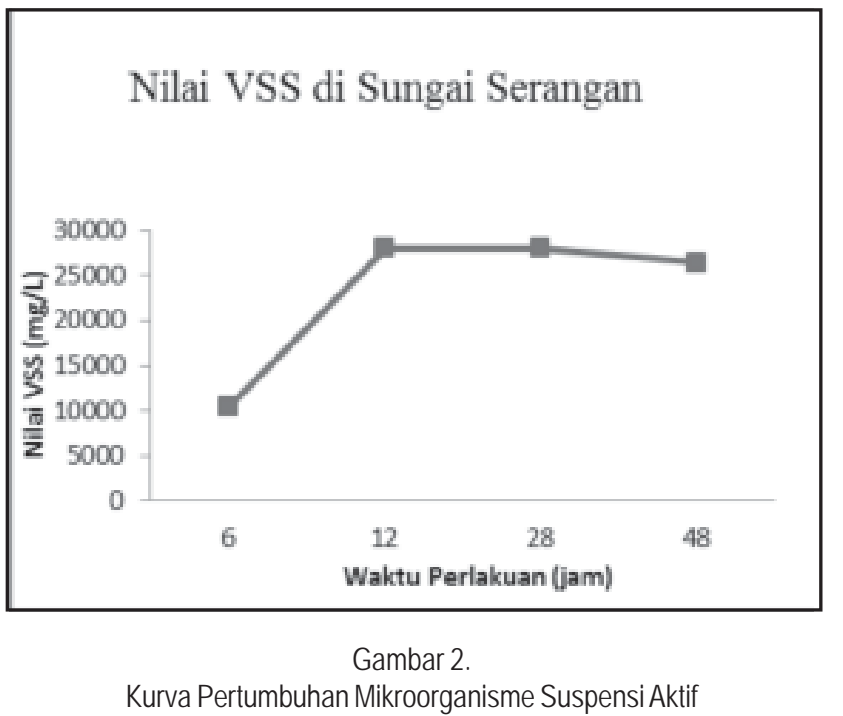

Dari Gambar 2, dapat dilihat bahwa pembibitan selama 48 jam terjadi peningkatan nilai VSS yang tajam pada waktu 6 sampai 12 jam yaitu dari 10400 menjadi $28000 \mathrm{mg} / \mathrm{L}$. Hal ini menunjukkan adanya aktivitas mikroorganisme, yang didukung oleh adanya media cair berupa nutrien yang cukup serta adanya aerasi sebagai sumber suplai oksigen. Aktivitas mikroorganisme ditandai dengan adanya pembelahan sel sehingga terbentuk sel baru pada sistem suspensi aktif (Soeparno,1992). Semakin tinggi aktivitas mikroorganisme dalam menguraikan bahan organik maka semakin tinggi pula biomassa yang dihasilkan. Peningkatan biomassa ini menyatakan jumlah bahan organik yang telah didegradasi oleh mikroorganisme (Atlas dan Bartha, 1987).

Pada Gambar 2, dapat dilihat bahwa terjadi peningkatan tajam nilai VSS terjadi pada jam ke 6 
sampai jam ke 12. Peningkatan nilai VSS terjadi karena adanya ketersediaan nutrisi ( bahan organik) yang diberikan serta pemberian oksigen dalam proses aerasi yang dapat menunjang ketersediaan oksigen terlarut dalam lumpur aktif. Penelitian ini didukung oleh Sudaryati, dkk (2011) bahwa peningkatan pertumbuhan mikroorganisme dan aktivitas mikroorganisme didukung oleh adanya cadangan makanan dan proses aerasi serta semua komposisi lumpur yang dibibit mengandung agen oksidator, sehingga akan memiliki kemampuan mengoksidasi bahan organik, baik secara kimia dan biologi. Jika dilihat dari kurva pertumbuhan nilai VSS yang diperoleh jam ke 12 , tidak terjadi peningkatan maupun pertumbuhan mikroorganisme yang disebut dengan fase stasioner. Hal ini disebabkan karena nutrien yang dibutuhkan oleh mikroorganisme mulai berkurang. Nutrien merupakan salah satu faktor yang mempengaruhi pertumbuhan sel mikroorganisme. Pada jam ke 28 sampai 48 terjadi penurunan kurva nilai VSS yang disebut dengan fase kematian. Hal ini terjadi akibat nutrisi dalam media cair sudah habis, sehingga pada fase ini terjadi kematian dari mikroorganisme tersebut. Oleh karena itu, waktu optimum pertumbuhan mikroorganisme dalam suspensi aktif yang diambil dari area mangrove di Serangan yaitu pada jam ke 12 .

Sumber bibit yang diambil dari sedimen tanah Sungai Serangan yang merupakan perairan tercemar yang mengandung limbah domestik dan kandungan bahan organik yang tinggi, yang dapat memberikan suasana yang baik bagi mikroorganisme dalam melakukan proses metabolisme. Dibuktikan dengan hasil pengamatan sebagian besar penduduk di sekitar sungai tersebut membuang sampah atau limbah ke sungai Serangan tersebut.

\subsection{Pengaruh Komposisi Bibit Mikroor- ganisme, Larutan Gula, dan Remazol Yellow FG dalam Penurunan Kadar Remazol Yellow FG.}

Waktu 12 jam merupakan waktu optimum pertumbuhan mikroorganisme pada sedimen Sungai Serangan. Adapun penurunan kadar Remazol Yellow FG selama 12 jam dengan komposisi yang berbeda disajikan dapat dilihat pada Tabel 1.

Berdasarkan tabel 1, pada komposisi media I terlihat bahwa kadar Remazol Yellow FG mengalami penurunan yang pesat pada perlakuan $12 \mathrm{jam}$. Hal ini dikarenakan kebutuhan nutrien bagi mikroorganisme masih mencukupi untuk berkembang biak dan mengalami penguraian sehingga pada waktu 12 jam, terjadi penurunan sebesar 14,553 mg/L. Pada komposisi media I merupakan komposisi yang mengandung glukosa lebih banyak dibandingkan dengan komposisi media II dan III. Pada komposisi media I terdiri dari 900 mL glukosa, 1950 mLlarutan Remazol Yellow $F G$ dan $150 \mathrm{~mL}$ larutan bibit. Mikroorganisme dengan bantuan kosubstrat seperti glukosa berfungsi sebagai donor elektron ke zat warna azo yang dikatalisis oleh enzim azo reductase sehingga terjadi pemutusan ikatan azo menghasilkan amina aromatik. Penurunan konsentrasi yang besar menandakan bakteri mampu mendegradasi zat warna.

Pada komposisi media II terlihat bahwa kadar Remazol Yellow FG mengalami penurunan yang lambat dibandingkan dengan komposisi I pada perlakuan 12 jam. Pada komposisi II, merupakan komposisi yang terdiri dari $600 \mathrm{~mL}$ glukosa, 2250 mL larutan Remazol Yellow FG dan 150 mL larutan bibit. Pada komposisi media II, penurunan konsentrasi zat warna sebesar 4,444 mg/L. Hal ini terjadi karena kebutuhan nutrien bagi mikroorganisme kurang mencukupi untuk berkembang biak sehingga kemampuan mikroorganisme dalam mendegradasi zat warna Remazol Yellow FG kurang maksimal.

Pada komposisi media III terlihat pada tabel bahwa penurunan konsentrasi terjadi sangat kecil bahkan dapat dikatakan tidak terjadi penurunan. Komposisi media III terdiri dari $300 \mathrm{~mL}$ glukosa, 2550 mL larutan Remazol Yellow FG, dan 150 mL larutan bibit. Pada komposisi ini, penurunan konsentrasi terjadi sebesar 0,664 $\mathrm{mg} / \mathrm{L} \mathrm{Hal} \mathrm{ini} \mathrm{terjadi} \mathrm{karena}$ nutrien yang tersedia sangat minim dengan jumlah mikroorganisme yang besar. Hal ini semakin memperbesar persaingan antar mikroorganisme untuk mendapatkan nutrien, sehingga kemampuan mikroorganisme untuk menurunkan konsentrasi air limbah Remazol Yellow FG semakin menurun (Soeparno,1992).

Komposisi media I merupakan komposisi optimum untuk menurunkan kadar Remazol Yellow $F G$ karna dalam waktu 12 jam dapat menurunkan kadar Remazol Yellow FG sebesar 14,553 mg/L. Pengaruh glukosa sangat berperan dalam proses pertumbuhan mikroorganisme. Semakin banyak kandungan glukosa, maka semakin banyak sumber nutrien bagi mikroorganisme untuk berkembangbiak dan semakin maksimal mikroorganisme melakukan degradasi terhadap zat warna azo.

Tabel 1. Penurunan Konsentrasi Remazol Yellow FG dengan Komposisi Media yang Berbeda

\begin{tabular}{lccc}
\hline Sampel & Konsentrasi Awal ( mg/L) & Konsentrasi Akhir( mg/L) & Penurunan Konsentrasi ( mg/L) \\
\hline Komposisi media I & 49,126 & 34,573 & 14,553 \\
Komposisi media II & 49,126 & 44,682 & 4,444 \\
Komposisi media III & 49,126 & 48,462 & 0,664 \\
\hline
\end{tabular}




\subsection{Penurunan kadar Remazol Yellow FG}

Pada penelitian ini ditentukan penurunan kadar Remazol Yellow FG dengan membandingkan hasil penurunan kadar Remazol Yellow FG dengan baku mutu air limbah domestik yang sudah ditetapkan.

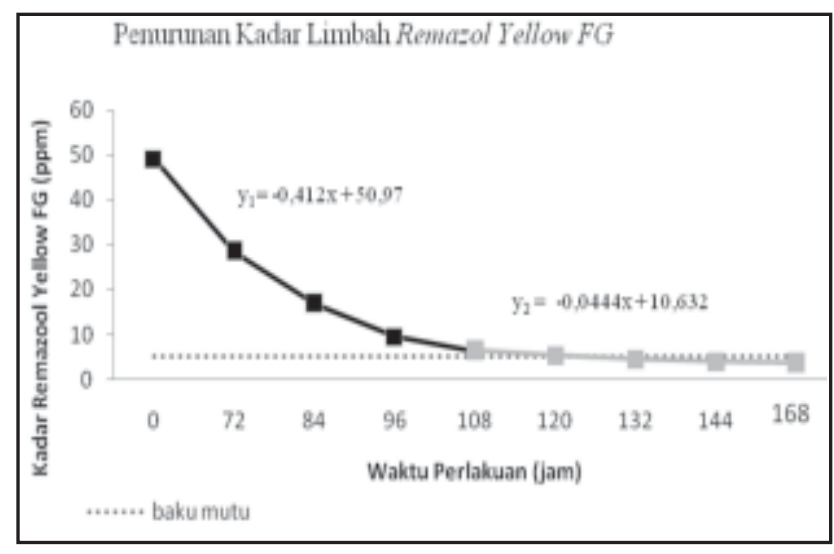

Gambar 3.

Kurva Kadar Remazol Yellow FG

Keterangan :

$y_{1}=$ persamaan garis laju penurunan cepat

$\mathrm{y}_{2}=$ persamaan garis laju penurunan lambat

Berdasarkan Gambar 3. menunjukkan bahwa karakteristik limbah Remazol Yellow FG sebelum dan sesudah didegradasi dengan sistem kombinasi anaerobik-aerobik dalam waktu $168 \mathrm{jam}$. Konsentrasi awal limbah Remazol Yellow FG sebesar 49,126 mg/ L. Setelah diolah selama 168 jam, konsentrasi limbah Remazol Yelow FG menjadi 3,6039 mg/L.

Pada Gambar 3, terjadi proses penurunan konsentrasi limbah Remazol Yellow FG yang cepat dari jam ke-0 hingga jam ke-96. Laju penurunan konsentrasi limbah Remazol Yellow FG dari jam ke0 hingga jam ke-96 adalah sebesar $0,412 \mathrm{mg} / \mathrm{L} / \mathrm{jam}$. Pada sistem pengolahan diawali dengan pengolahan secara anaerobik selama 72 jam. Pada penelitian ini, pengolahan anaerobik merupakan pengolahan pendahuluan untuk mendegradasi senyawa-senyawa organik kompleks berantai panjang menjadi senyawa yang lebih sederhana agar mudah terdegradasi dalam kondisi aerob. Pada proses anaerob terjadi degradasi zat warna yang ditandai dengan perubahan warna dari kuning pekat menjadi tak berwarna. Penghilangan zat warna terjadi karena pemutusan ikatan kromofor gugus azo pada zat warna Remazol Yellow FG. Terjadinya penghilangan warna membuat senyawa aromatik berantai panjang ( zat warna) menjadi senyawa aromatik berantai pendek (Kun dkk,1992). Hasil penelitian ini sesuai dengan pernyataan Brohm dan Frowein (1997) yang ditunjukkan pada Gambar 4.

Pada jam ke 84 dan jam ke 96 merupakan hasil pengolahan secara aerob, terjadi degradasi senyawa aromatik berantai pendek yang dihasilkan dari pengolahan anaerob. Hal ini ditunjukkan oleh

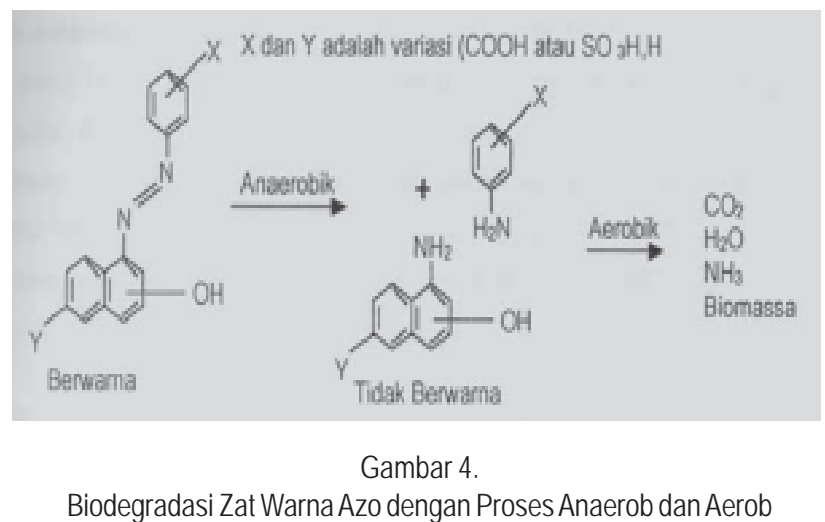

konsentrasi dari zat warna Remazol Yellow FG mengalami penurunan setelah pengolahan. Hal ini juga disebabkan oleh kebutuhan nutrien bagi mikroorganisme masih mencukupi untuk berkembang biak serta melaksanakan aktivitas penguraian. Ketika memasuki waktu pengolahan ke 108 jam hingga $168 \mathrm{jam}$, laju kurva penurunan kadar Remazol Yellow FG mulai melambat. Laju penurunan konsentrasi limbah Remazol Yellow FG dari jam ke 108 hingga jam ke 168 adalah sebesar $0,0444 \mathrm{mg} / \mathrm{L} / \mathrm{jam}$. Hal ini disebabkan kondisi mikroorganisme mulai kehabisan sumber nutrien dan tidak ada tambahan nutrien lagi sehingga mikroorganisme tidak bisa melakukan pertumbuhan dan proses penguraian akan semakin menurun yang disebut dengan keadaan stationary phase. Penurunan kadar Remazol Yellow FG disebabkan karena zat warna terdegradasi menjadi senyawasenyawa yang lebih sederhana yaitu $\mathrm{CO}_{2}$ dan $\mathrm{H}_{2} \mathrm{O}$ oleh aktivitas mikroorganisme, dimana terjadi perombakan zat warna $a z o$ yang merupakan reaksi redoks. Mikroorganisme memerlukan kosubstrat berupa senyawa karbon organik seperti glukosa untuk mempercepat perombakan zat warna azo. Glukosa dalam sistem biologi mengalami proses glikolisis dengan bantuan enzim dehydrogenase menghasilkan koenzim nikotinamida adenine dinukleotida (NADH). Koenzim NADH yang dihasilkan dari proses glikolisis glukosa mentransfer elektron ke zat warna azo yang dikatalisis oleh enzim reductase. Koenzim NADH mengalami reaksi oksidasi menghasilkan $\mathrm{NAD}^{+}$sedangkan zat warna azo mengalami reduksi menghasilkan senyawa amina aromatik yang tidak berwarna.Selanjutnya pada tahap perombakan aerob, amina aromatik diuraikan lebih lanjut menghasilkan senyawa yang lebih sederhana. Kadar Remazol Yellow FG jika dibandingkan dengan hasil baku mutu air limbah domestik yang ditentukan, setelah mengalami pengolahan selama 168 jam secara anaerob dan aerob, kadar Remazol Yellow FG sudah berada dibawah baku mutu. Kadar Remazol Yellow FG setelah pengolahan sebesar 3,6039 mg/L. Hal ini menandakan bahwa kemampuan mikroorganisme dalam memutuskan ikatan azo mampu menurunkan 
kadar zat warna dibawah baku mutu yang ditetapkan. Hal ini sesuai dengan Manurung (2004) yang menyatakan bahwa lumpur atau sedimen sungai berpotensi sebagai bahan lumpur aktif yang mampu menurunkan logam berat dan limbah domestik dalam limbah cair.

\subsection{Efektivitas Biodegradasi Zat Warna Remazol Yellow FG dalam Sistem Mikrobial}

Efektivitas dari biodegradasi zat warna Remazol Yellow FG dalam menurunkan kadar Remazol YellowFG ditunjukkan dalam Tabel 2.
Pada sampel ke II, nilai TPC mengalami penurunan. Hal ini dikarenakan mikroorganisme telah mengalami kontak dengan zat warna sehingga pertumbuhan mikroorganisme terganggu. Selain itu, kemungkinan kompetisi antar mikroorganisme untuk mendapatkan nutrien telah berlangsung sehingga dengan semakin berkurangnya nutrien mengakibatkan mikroorganisme yang kurang mampu berkompetisi akan mati. Pada sampel III, terlihat nilai TPC meningkat. Hal ini dikarenakan mikroorganisme yang mampu berkompetisi dan bertahan memperoleh sumber energi kembali dari proses penguraian oleh senyawa-senyawa yang terjadi

Tabel 2. Efektivitas Biodegradasi dalam Menurunkan Konsentrasi limbah Remazol Yellow FG

\begin{tabular}{cccc}
\hline Waktu(jam) & KonsentrasiAwal $(\mathrm{mg} / \mathrm{L})$ & Konsentrasi akhirRata-rata( $\mathrm{mg} / \mathrm{L})$ & Efektivitas $(\%)$ \\
\hline 0 & 49,126 & 49,126 & 0 \\
72 & 49,126 & 28,408 & 42,17 \\
84 & 49,126 & 16,875 & 65,65 \\
96 & 49,126 & 9,533 & 80,59 \\
108 & 49,126 & 6,353 & 87,07 \\
120 & 49,126 & 5,137 & 89,54 \\
132 & 49,126 & 4,404 & 91,03 \\
144 & 49,126 & 3,796 & 92,27 \\
168 & 49,126 & 3,604 & 92,66 \\
\hline
\end{tabular}

Berdasarkan pada tabel 2, efektivitas dari biodegradasi zat warna Remazol Yellow FG dalam sistem mikrobial terbesar pada saat waktu pengolahan jam ke 168. Hal ini menunjukkan bahwa pada waktu jam ke 168 mikroorganisme dapat bekerja optimum dalam mendegradasi limbah zat warna Remazol Yellow FG hingga berada di bawah baku mutu. Hal itu terjadi karena kemampuan bakteri dalam menguraikan limbah zat warna Remazol Yellow FG semakin berkurang, namun tetap meningkatkan efektivitas setiapjamnya hingga mencapai 92,66 \% pada jam ke- 168 .

\subsection{Identifikasi Mikroorganisme yang Berperan dalam Menurunkan Kadar Remazol Yellow FG}

Menurut Chojnacka (2010) Bakteri yang diisolasi dari lingkungan tercemar zat warna tekstil sangat berpotensi sebagai agen biodegradasi zat warna, sebab bakteri tersebut akan memiliki daya resistensi dan toleransi pada zat warna yang ada di sekitarnya. Dari hasil uji identifikasi diperoleh hasil jumlah total mikroorganisme seperti pada tabel 3.

Dari Tabel 3. diketahui bahwa TPC untuk sampel I, II, III secara berturut-turut adalah $2,84 \times 10^{2} \mathrm{CFU} /$ $\mathrm{mL}, 1,24 \times 10^{2} \mathrm{CFU} / \mathrm{mL}, 2,08 \times 10^{2} \mathrm{CFU} / \mathrm{mL}$. Pada sampel I, nilai TPC lebih besar dari sampel II dan III dimungkinkan karena pada sampel I masih tersedia nutrien yang berlimpah, sehingga pertumbuhan mikroorganisme menjadi maksimal. pada proses biodegradasi, sehingga nilai TPC mengalami kenaikan. Hasil identifikasi dari TPC (Total Plate Count) disajikan pada Gambar 5.

Adapun hasil identifikasi bentuk sel dengan metode pewarnaan dari awal hingga akhir proses biodegradasi diperoleh hasil seperti pada Gambar 6 .

Dari Gambar 5 dan 6 diketahui bahwa bakteri yang terdapat pada proses biodegradasi adalah Bacillus sp, Coliform, Pseudomonas sp, Staphylococcus sp. Bakteri-bakteri inilah mampu mendegradasi limbah zat warna Remazol Yellow FG. Pada penelitian yang dilakukan oleh Suyasa, et al ( 2016 ) mikroorganisme yang teridentifikasi dalam proses biodegradasi Rhodamin B dalam biosistem yaitu Pseudomonas sp dan yeast. Pseudomonas sp dalam mendegradasi Rhodamin B memiliki efektivitas sebesar $24,20 \%$.

Tabel 3. Hasil Identifikasi Jumlah Total Mikroorganisme

\begin{tabular}{cc}
\hline Kode Sampel & TPC ( Total Plate Count ) ( CFU/mL) \\
\hline I & $2,84 \times 10^{2}$ \\
II & $1,24 \times 10^{2}$ \\
III & $2,08 \times 10^{2}$ \\
\hline
\end{tabular}

Ket :

I : Sampel air awal pengolahan biodegradasi pada jam ke - 84

II :Sampel air pertengahan pengolahan biodegradasi pada jam ke-120

III : Sampel air akhir pengolahan biodegradasi pada jam ke - 168 


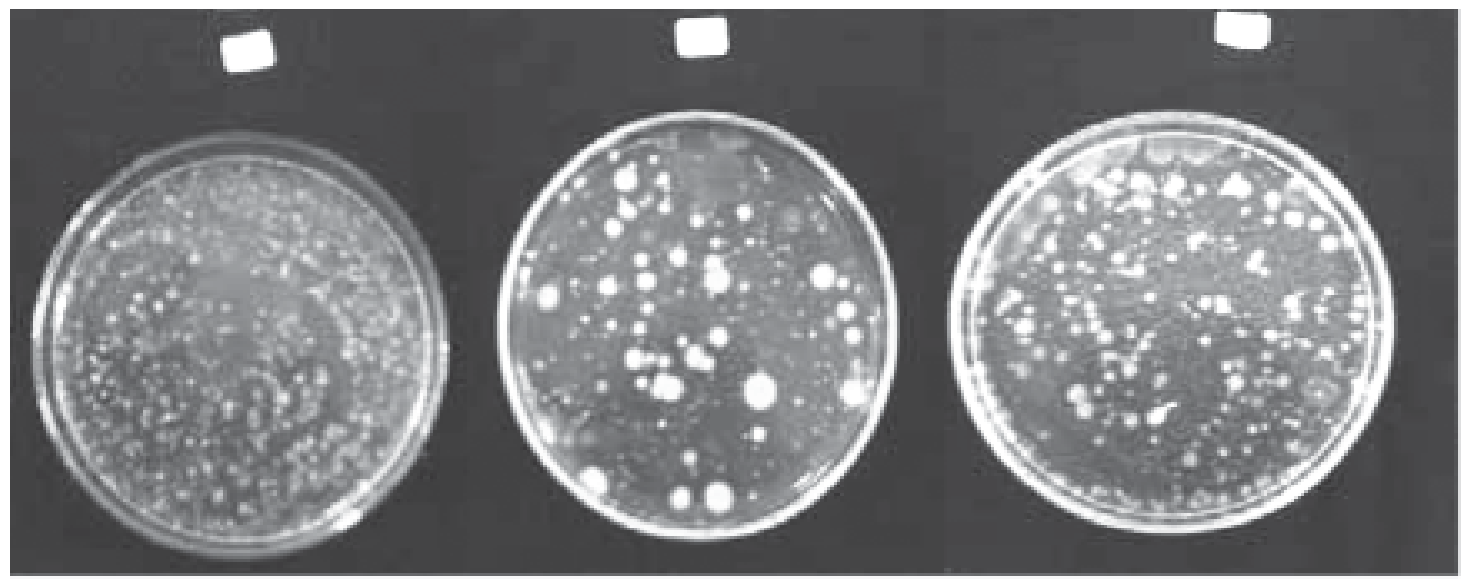

(a)

(b)

(c)

Gambar 5.

Hasil identifikasi TPC sampel air (a) di awal pengolahan, (b) pada pertengahan pengolahan dan (c) di akhir pengolahan proses biodegradasi Remazol Yellow FG.

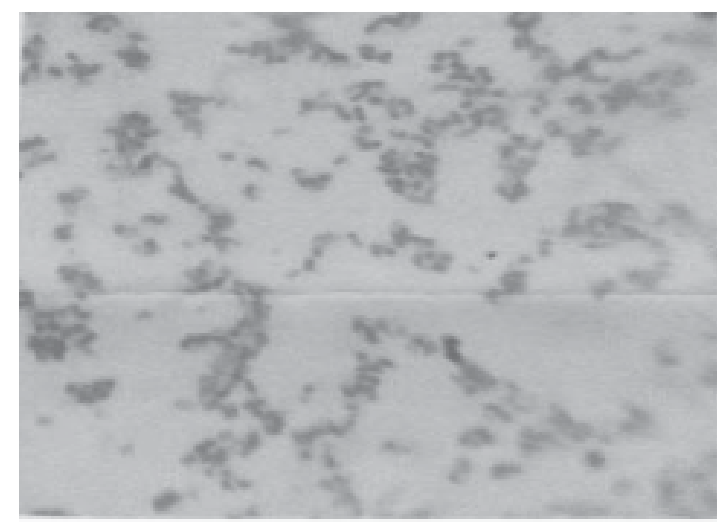

(a)

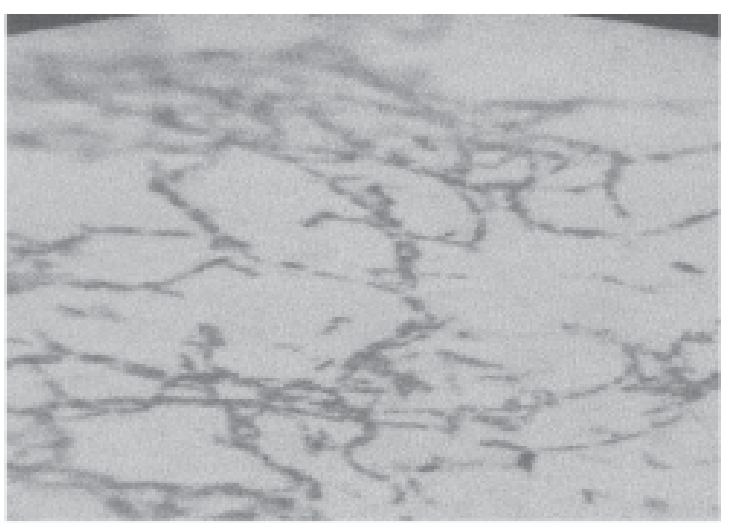

(b)

Gambar 6.

Hasil pewarnaan (a) Staphylococcus sp dan (b) Bacillus sp.

\section{SIMPULAN DAN SARAN}

\subsection{Simpulan}

1. Waktu pembibitan suspensi aktif optimum yaitu 12 jam dengan perolehan nilai VSS tertinggi sebesar $28000 \mathrm{mg} / \mathrm{L}$.

2. Komposisi terbaik dalam menurunkan kadar Remazol Yellow FG yaitu Komposisi media I yang terdiri dari $900 \mathrm{~mL}$ larutan glukosa, 1950 mL larutan Remazol Yellow FG, dan 150 mL larutan bibit dari suspensi aktif.

3. Laju penurunan kadar Remazol Yellow FG terjadi sangat cepat pada jam ke 0 sampai 96 jam. Laju penurunan kadar Remazol Yellow FG mulai lambat pada jam ke 108 sampai 168 jam sehingga memiliki efektivitas sebesar $92,66 \%$.

4. Bakteri yang dominan berperan dalam menurunkan kadar Remazol Yellow FG teridentifikasi yaitu Bacillus sp, Coliform, Pseudomonas sp dan Staphylococcus sp. Jumlah koloni di awal pengolahan sebesar 2,84 x $10^{2} \mathrm{CFU/}$
$\mathrm{mL}$, diwaktu pertengahan pengolahan diidentifikasi sebesar $1,24 \times 10^{2} \mathrm{CFU} / \mathrm{mL}$, dan di akhir proses degradasi diperoleh sebesar $2,08 \times 10^{2} \mathrm{CFU} / \mathrm{mL}$.

\subsection{Saran}

1. Perlu dilakukan penelitian menggunakan limbah zat warna langsung dari industri tekstil.

2. Perlu dilakukan penelitian lebih lanjut mengenai nilai VSS pada rentang waktu 0 sampai 12 jam.

\section{DAFTAR PUSTAKA}

Atlas, R. M and R. Bartha, 1987, Microbial Ecology : Fundamentals and Applications, $2^{\text {nd }}$ ed, Menlo Park : The Benjamin/ Cummings Pibl, Co., Inc.

Brown, D. dan Hamburger, B., 1997, The degradation of dyestuffs.investigation of their ultimate degradability, Chemosphere16:1539-1553 
Chojnacka, K.2010. Biosorption and nioaccumulation, The prospects for practical applications. Environment International, 36, 299-307.

Manurung, Renita.,2004, Perombakan Zat Warna Azo Reaktif Secara Anaerob-Aerob, Jurusan Teknik Kimia Universitas Sumatera Utara

Metcalf And Eddy, 2003, Wastewater Engineering, Treatment and Reuse, Fourth Edition, McGraw Hill Higher Education, New York.

Rasjid D, G.A. Kosoenarno, Astini S, Arifin L., 1976, Teknologi Pengelantangan, Pencelupan, dan Pencapan, Institut Teknologi Tekstil. Bandung

Soeparno, 1992, Ilmu dan Teknologi Daging, Gajah Mada University, Yogyakarta.

Sudaryati, YS., Rahayu, SH., Setianingrum, N., Niola, E, 2011, Kemampuan Bacillus licheniformis dalam Memproduksi Enzim
Protease yang Bersifat Alkalin dan Termofilik, Artikel, Media Litbang Kesehatan Volume 21 Nomor 2 Tahun 2011.

Sugiharto, 1987, Dasar - Dasar Pengolahan Air Limbah, Universitas Indonesia, Jakarta

Suyasa, Wayan Budiarsa, 2015, Pencemaran Air dan Pengolahan Air Limbah, Udayana University Press, Denpasar

Suyasa, I. W. B., dan Dwijani, W., 2015, Biosystem Treatment Approach for Seaweed Processing Wastewater, Journal of Environment and Waste Management,Vol.2(2),page: 059-062.

Suyasa W.B. et al, 2016, Main Role of Microbialin Rhodamin B Biodegradation, International Journal of Pharmacy \& Technology, Vol.8, page: 14399-14408. 